\title{
HETEROGENEOUS SPILLOVERS OF HOUSING CREDIT POLICY.
}

Myrostav Pidkny 10

Documentos de Trabajo. N. 1940

\section{BANCODE ESPANA}

\author{
Eurosistema
}

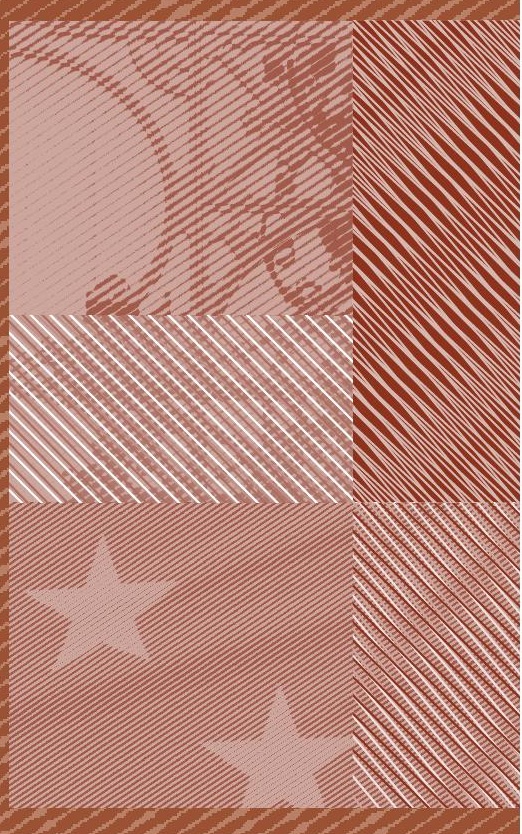


HETEROGENEOUS SPILLOVERS OF HOUSING CREDIT POLICY 
HETEROGENEOUS SPILLOVERS OF HOUSING CREDIT POLICY(*)

\author{
Myroslav Pidkuyko ${ }^{(*)}$
}

BANCO DE ESPAÑA

(*) Myroslav Pidkuyko acknowledges the financial support from the Economic and Social Research Council UK [grant number ES/J500094/1]. I am especially indebted to Raffaele Rossi, Klaus Reiner Schenk-Hoppé and Ákos Valentnyi for their guidance at the the early stages of this project. I am very grateful to Patrick Macnamara and Panagiotis Margaris for numerous helpful conversations. I am also thankful to Árpád Ábrahám, Peter Backus, James Banks, Henrique S. Basso, Ambrogio Cesa-Bianchi, Clodomiro Ferreira, Agnes Kovacs, Felix Kubler, Morten Ravn, José Víctor Ríos Rull, Karl Schmedders, Adam Szeidl, seminar participants at Lancaster University, The University of Manchester, University of Zurich, University of Amsterdam, University of Naples, University of Helsinki, University of Padova, University of Surrey, Banco de España, Bank of Lithuania, conference participants at CEF2018 in Milan, XXIII Workshop On Dynamic Macroeconomics in Vigo and RES2019 in Warwick for helpful comments. Finally, I would like to thank the anonymous referee for helpful comments and suggestions. The views expressed in this paper are those of the author and do not necessarily represent the views of the Banco de España and the Eurosystem. Remaining errors are the authors'.

$\left.{ }^{(\star}\right)$ Banco de España, Madrid, Spain. Email: myroslav.pidkuyko@bde.es. Web: www.myroslavpidkuyko.com. 
The Working Paper Series seeks to disseminate original research in economics and finance. All papers have been anonymously refereed. By publishing these papers, the Banco de España aims to contribute to economic analysis and, in particular, to knowledge of the Spanish economy and its international environment.

The opinions and analyses in the Working Paper Series are the responsibility of the authors and, therefore, do not necessarily coincide with those of the Banco de España or the Eurosystem.

The Banco de España disseminates its main reports and most of its publications via the Internet at the following website: http://www.bde.es.

Reproduction for educational and non-commercial purposes is permitted provided that the source is acknowledged.

(C) BANCO DE ESPAÑA, Madrid, 2019

ISSN: 1579-8666 (on line) 
Abstract

We study the spillovers from government intervention in the mortgage market on households' consumption using the household survey data from the US. After an expansionary mortgage market operation, the increase in consumption of homeowners with mortgage debt is large and significant, while the consumption response of homeowners without the mortgage debt is small and insignificant. Non-homeowners also increase their consumption but less than mortgagors. We also find that expansionary policy significantly increases the consumption inequality of mortgagors. We explain these facts through the lens of a lifecycle model with incomplete markets and endogenous housing choice. Reduction in credit rates creates extra wealth for the mortgagors while a reduction in interest rates shifts this wealth towards consumption. An increase in wealth is bigger for those with a larger mortgage- this exacerbates consumption inequality.

Keywords: mortgage debt, life-cycle models, government-sponsored enterprises, credit policy.

JEL classification: E21, E44, R38, G28. 


\section{Resumen}

Este artículo estudia cómo las políticas públicas de intervención en el mercado hipotecario afectan al consumo de los hogares utilizando los datos de la encuesta de hogares de los EE.UU. La política pública analizada consiste en compras públicas en el mercado secundario de hipotecas ya concedidas. Se demuestra empíricamente que, después de las compras públicas, aumenta el gasto de los hogares con hipotecas, y en menor medida de quienes alquilan su vivienda, pero no el de los hogares propietarios no endeudados. Las compras públicas aumentan también la desigualdad en el gasto de los hogares con hipoteca. Estos resultados se explican por un modelo de ciclo vital y mercados incompletos en el que los hogares deciden cuánto gastar en vivienda. La reducción del coste de crédito genera riqueza adicional para los endeudados, y la caída de los tipos de interés canaliza este aumento de riqueza hacia el gasto. Al ser mayores los efectos entre los hogares con hipoteca más elevada, las compras públicas de hipotecas aumentan la desigualdad en el gasto.

Palabras clave: deuda hipotecaria, modelo de ciclo vital, empresas patrocinadas por el gobierno, política de crédito.

Códigos JEL: E21, E44, R38, G28. 


\section{Introduction}

Activity in secondary mortgage markets boosts mortgage lending, lowers mortgage rates and influences prices on other financial markets (Fieldhouse, Mertens and Ravn, 2018). In this paper, we study how this activity affects the largest component of GDP, household consumption. We show that households' financial position is crucial in understanding the spillovers from the activity in secondary mortgage markets to private consumption. We proxy households' financial position through housing tenure status. First, we show empirically, that following an expansionary policy change to the secondary mortgage markets, homeowners with mortgage debt increase their spending substantially, while homeowners without the mortgage debt do not react to policy change. Nonhomeowners also increase their consumption but less than mortgagors. We also show that the same expansionary policy significantly increases the consumption inequality of mortgagors. Second, to explain this empirical evidence, we present a life-cycle model with incomplete markets and endogenous housing choice in the vein of Kaplan, Mitman and Violante (2018); Favilukis, Ludvigson and Van Nieuwerburgh (2017); Sommer and Sullivan (2018); Wong (2019). In our policy experiment, we reproduce the macroeconomic effects of credit policy changes of Fieldhouse, Mertens and Ravn (2018) and simultaneously cut both interest and mortgage rates as well as the spread between the two. Lower mortgage rates imply lower mortgage payments for the mortgagors and hence a rise in long-term permanent income for this group. Lower interest rates imply that part of this extra income goes to consumption rather than saving. In the model, wealth is a function of house size and thus the mortgage size. Lower mortgage payments generate a higher increase in wealth that in turn increases inequality among the mortgagors.

In our empirical exercise, we explore the link between expansionary credit policy changes and an increase in households' expenditure. In particular, we focus on credit policy changes through exogenous governmental intervention in the mortgage markets via various federal housing agencies, and mortgage assets purchases of these agencies. For the most part, credit policy changes are a reaction to business cycle conditions (the most recent QE3 being the prime example). To analyze the response of consumption to any of these policy changes, it is, therefore, important to isolate the policy changes that are orthogonal to the business cycle (such as long-term objectives of increasing the homeownership). We combine the exogenous non-cyclically motivated events from Fieldhouse 
and Mertens (2017) with mortgage purchases of the two largest federal housing agencies (Fannie Mae and Freddie Mac). We then use the former as an instrument in regressions of households' consumption on measures of agency purchase activity. We measure consumption using household-level data from the Consumer Expenditure Survey and the Survey of Consumer Finances. If credit market interventions were neutral (Meltzer, 1974; Greenspan, 2005; Lehnert, Passmore and Sherlund, 2008; Fieldhouse, Mertens and Ravn, 2018) an increase in agency purchases should have little impact on private consumption. What we find empirically, is that credit policy changes lead to an increase in private consumption of mortgagors and an increase in consumption inequality for this group.

In our theoretical exercise, we use a structural model to identify the transmission mechanism we found in our reduced-form analysis. We model the credit policy change experiment by replicating the aggregate macroeconomic effect of mortgage market interventions documented in Fieldhouse, Mertens and Ravn (2018). In particular, we focus on change in both interest and mortgage rates as well as on change in the spread between the two. Our first finding is that lower mortgage rates imply lower mortgage payments for the mortgagors and a rise in long-term permanent income for this group. In terms of mechanisms in the model, we identify the access to refinancing as a crucial transmission mechanism for expansionary credit policy. These results are in line with both the recent microeconomic evidence (Wong (2019) emphasizes the role of refinancing for transmission of monetary policy to consumption) as well as macroeconomic evidence (following a credit policy shock Fieldhouse, Mertens and Ravn (2018) show an increase of mortgage originations due to refinancing). Since the opportunity cost of saving goes down when the interest rates drop as well - mortgagors consume this extra income instead of saving. The results we find are also in line with Cloyne, Ferreira and Surico (2018), who argue that the behavior of mortgagors resembles that of wealthy hand-to-mouth households and empirically document a similar response of individual consumption to expansionary monetary policy shock. Indeed, in the model, mortgagors hold little liquid wealth, outstanding mortgage debt and illiquid assets in the form of the house. We then analyze the response of other types of households: renters and outright homeowners. Similarly to mortgagors, renters' utility from consumption outweighs that of saving, and they consume more once the new credit policy is at hand. For outright homeowners, who are mostly older than renters and mortgagors, any changes in the interest rate will have a very small effect, given that the marginal propensity to consume for these households is already quite low. 
On top of that, with the presence of the bequest motive, it will outweigh that of dissaving one, and the homeowners will increase consumption and save instead. Using the same policy experiment, we also reproduce the increase in consumption inequality. In the model, net wealth depends on assets and on mortgage outstanding (that is zero for both renters and outright homeowners). The increase in wealth is larger for households with a bigger mortgage (and therefore bigger house), generating a heterogeneous response of consumption increase within the mortgagors' group.

Related Literature. In exploring the link between exogenous credit policy changes and individual consumption our paper adds to both empirical and theoretical literature on housing and mortgage markets. From the empirical side, we relate to four strands of literature. Firstly, we analyze the US federal government interventions into the mortgage markets. For the most part the literature focused on governments' intervention in terms of tax policies. Recent studies include Chambers, Garriga and Schlagenhauf (2009); Hilber and Turner (2014); Floetotto, Kirker and Stroebel (2016); Sommer and Sullivan (2018), among others. Fieldhouse, Mertens and Ravn (2018) is the most recent study that instead analyzes the interventions to the federal housing agencies, rather than any tax policies. In this paper, we use exogenously identified policy interventions from Fieldhouse, Mertens and Ravn (2018); unlike Fieldhouse, Mertens and Ravn (2018), however, we analyze the transmission mechanisms through which the policy operates using the US household survey data.

Secondly, this paper is related to literature that analyzes the interaction between federal housing agencies and other markets. The most recent studies include GonzalezRivera (2001); Naranjo and Toevs (2002); Lehnert, Passmore and Sherlund (2008); Hancock and Passmore $(2011,2014)$ as well as Fieldhouse, Mertens and Ravn (2018). We focus specifically on the effect of mortgage purchases of governmental housing agencies on consumption of different types of households using a novel identification strategy.

Thirdly, our paper is related to the literature on the role of household balance sheet channels in the transmission of monetary and fiscal policy shocks. These include Iacoviello (2005); Eggertsson and Krugman (2012); Luetticke (2015); Greenwald (2016); Hedlund et al. (2016); Cloyne, Ferreira and Surico (2018); Kaplan, Moll and Violante (2017); Auclert (2017); Bilbiie (2017), to name a few. Coibion et al. (2017) also uses US household level data to study the effect of conventional monetary policy on income and consump- 
tion inequality. Like in Cloyne, Ferreira and Surico (2018), we use the households' housing tenure status to proxy their asset and debt position.

Finally, this paper is related to literature that analyzes the effects of monetary policy shocks on inequality. Coibion et al. (2017) uses US household level data to study the effect of conventional monetary policy on income and consumption inequality. We follow Coibion et al. (2017) methodology to construct the measure of expenditure inequality between all types of households as well as within each housing tenure group. Unlike Coibion et al. (2017) we focus on the effect of credit policy shocks on expenditure inequality.

From the theoretical side, our model resembles the recent literature that extends Huggett (1996) model to incorporate housing decision and aggregate housing and mortgage markets. To name a few, we build on the models of Kaplan, Mitman and Violante (2018); Favilukis, Ludvigson and Van Nieuwerburgh (2017); Sommer and Sullivan (2018); Wong (2019), that analyze heterogeneous agents life-cycle economies with uninsurable income risk in which households make a housing and mortgage choice. Unlike these papers, however, we do not focus on the aggregate implications of different macroeconomic shocks but rather analyze the individual households' behavior.

Structure of the Paper. The rest of the paper is structured as follows. Section 2 sets out the empirical model and presents the impulse response analysis. Section 3 develops a life-cycle economy with endogenous housing choice and uninsurable idiosyncratic risk. Section 4 calibrates the model and describe the properties of the baseline economy. Section 5 analyzes the effect of mortgage market intervention within the model framework and discusses transmission mechanisms. Finally, section 6 concludes.

\section{Empirical Framework}

\subsection{Institutional Background and Identification of Exogenous Policy Changes}

The total mortgage debt in the US accounts for about $80 \%$ of total household debt. For instance, by the 3rd quarter of 2017, the total mortgage debt was about $\$ 8.7$ trillion, while 
auto, credit card and student debt combined were about $\$ 2.3$ trillion. Furthermore, this debt goes towards financing the largest asset in the households' net worth - housing. ${ }^{1}$

The US mortgage market is also unique. The US federal government is heavily involved in the mortgage market (especially in terms of residential mortgage purchases) though various agencies: Government-Sponsored Enterprises (GSEs) and Government Agencies (see Fieldhouse and Mertens (2017); Fieldhouse, Mertens and Ravn (2018) for detailed history and overview of how these agencies operate). Given the data availability, in this paper, we focus on the involvement of the government through the two largest GSEs: Fannie Mae, founded in 1938 and publicly traded since 1968, and Freddie Mac, founded in 1970. These agencies were established by Congress to support secondary mortgage markets by buying and securitizing loans from primary mortgage lenders; they are not, however, allowed any direct lending. The share of mortgage debt held by these agencies grew substantially since their establishment and reached a peak of almost $20 \%$ by 2004 , slowly declining ever since. Figure 1 plots the agency mortgage holdings as a share of total mortgage debt in the US over time. See Appendix A for a detailed description of the data.

In the empirical section of this paper, we focus on the portfolio purchases of the housing agencies, shown in the solid blue line in Figure 2, and how it affects expenditure of households with different debt position. Unfortunately, simply correlating measures of agency activity with households' expenditure ignores potential endogeneity problems (see Fieldhouse, Mertens and Ravn (2018)). On one hand, Fannie Mae and Freddie Mac respond to market conditions and thus act pro-cyclically. On the other hand, Fannie Mae and Freddie Mac's role is to provide stability on the mortgage markets and thus act counter-cyclically. Ignoring these potential problems makes the causal inference invalid.

To account for the endogeneity in agency market activity we use a narrative identification approach and use major regulatory policy events as an instrument for agency purchase activity. Fieldhouse and Mertens (2017) document significant policy changes that are expected to affect agency portfolios and isolate those events (which they call noncyclical events) that are free of confounding influences in the spirit of Romer and Romer (2004) and Ramey (2011). These policy changes are indicated by vertical red lines in Figure 2. We quantify these changes by taking a calculated impact of these policies changes

\footnotetext{
${ }^{1}$ For example, in the 2001 wave of the Survey of Consumer Finances that we use in this paper, the average household held more than $60 \%$ of his net worth in housing. Source: Author's calculations.
} 
Figure 1: Agency mortgage holdings as a percent of total mortgage originations. Data is between 1980 and 2016. Grey areas represent NBER recessions. Source: Authors own calculations.

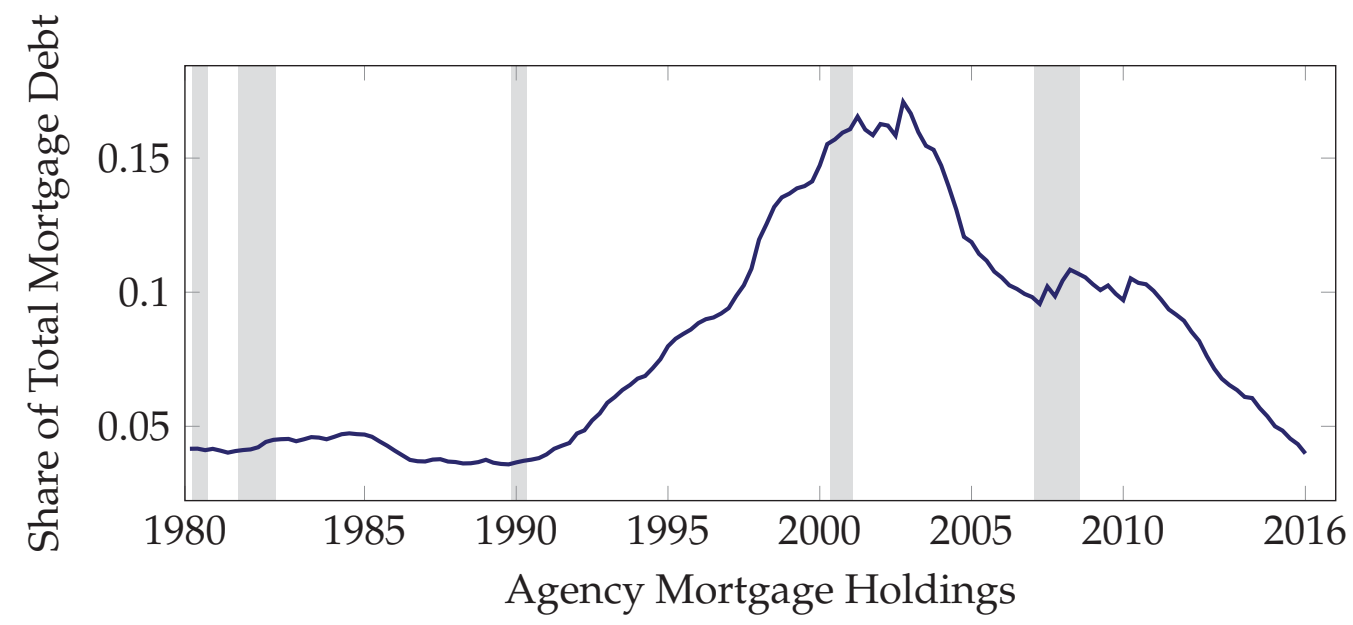

Figure 2: FNMA \& FHLMC net purchase for portfolio investment. Data is between 1980 and 2016. Grey areas represent NBER recessions. Source: Author's own calculations (agency net purchases) and Fieldhouse and Mertens (2017) (policy changes).

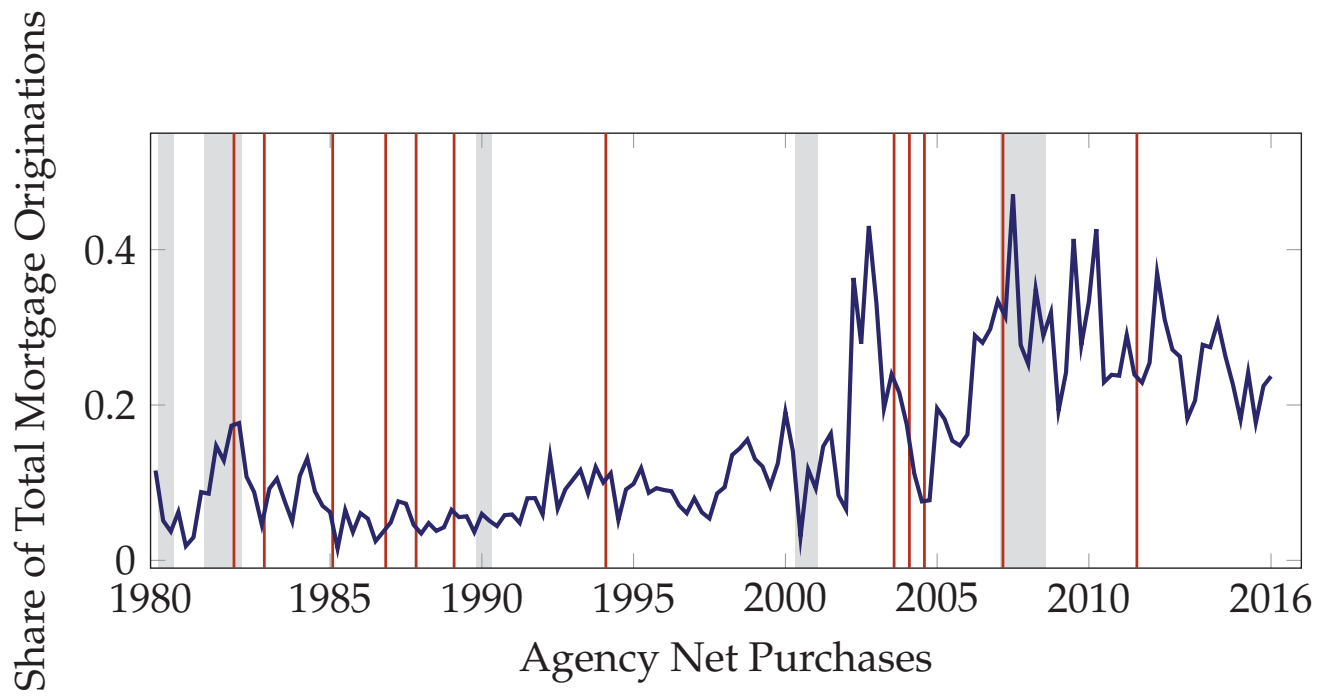

from Fieldhouse and Mertens (2017) and dividing by the average annualized level of originations in the preceding year. As most of the policy interventions after 2006 were related to the 2007 / 2008 financial crisis and were mostly cyclically motivated, we limit the analysis to the pre-crisis sample.

\subsection{Impulse Response Specification}

To evaluate the effect of agency purchase activity on households' consumption we conduct an impulse response analysis of shock to agency mortgage purchase. We use a 
local projections instrumental variable approach in the spirit of Jordà (2005) where we use the narrative instrument for identification.

Following Fieldhouse, Mertens and Ravn (2018), we start by assessing whether the narrative policy changes do lead to significant changes in net agency purchases. Our firststage regression specification is of the form

$$
\frac{\sum_{j=0}^{h} p_{t+j}}{X_{t}}=\tilde{a}_{h}+\tilde{c}_{h} \frac{\tilde{m}_{t}}{X_{t}}+\tilde{d}_{h}(L) Z_{t-1}+\tilde{u}_{t+h}
$$

where $p_{t}$ is the agency's net purchase, $X_{t}$ trend in real mortgage originations, $\tilde{m}_{t}$ is noncyclically motivated narrative measure in real dollars, and $Z_{t}$ is a set of controls (defined below). $\tilde{d}_{h}(L)$ denotes the polynomial of order 4 . We pick the value of horizon $h$ for which out instrument is the strongest. For that, we run regression (1) for horizons $h=1$ (one quarter) to $h=20$ (five years) and pick $h$ that maximizes the robust F-statistics on the excluded instrument for each $h$. The F-test statistics exceeds 10 for horizons between 1 and 3 quarters, indicating that the narrative measure is a strong predictor of agency purchases for this horizon. The F-statistics declines for longer horizons. ${ }^{2}$ Given these results we restrict the analysis to horizons between 1 and 3 quarters. Specifically, we focus on the agency purchase activity 2 quarters after the shock, as the robust F-statistic is the highest and equal to 15. Figure B.1 in Appendix B shows the robust F-statistics on the excluded instrument in each of the first-stage regressions (1) for horizons $h=1$ (one quarter) to $h=20$ (five years).

We now proceed to identifying the effect of agency purchase activity on variable of interest. Our goal is to identify the response to shocks to expectations of future agency purchasing activity. For a given outcome variable $y_{t}$, we estimate the response at horizon $h$ using

$$
\frac{y_{t+h}-y_{t-1}}{y_{t-1}}=a_{h}+b_{h}\left(\frac{4}{2} \times \frac{\sum_{j=0}^{2} p_{t+j}}{X_{t}}\right)+d_{h}(L) Z_{t-1}+u_{t+h}
$$

where

$$
\frac{4}{2} \times \frac{\sum_{j=0}^{2} p_{t+j}}{X_{t}}
$$

denotes net agency purchases made over a 2 quarter period, divided by annualized originations $X_{t}$; where the choice of 2 quarters horizon is based on the first-step regression.

\footnotetext{
${ }^{2}$ Using monthly data, Fieldhouse, Mertens and Ravn (2018) find that narrative measure is a strong predictor for the horizons between 4 to 48 months, that is in line with our estimates.
} 
The regression in (2) estimates the quarter $h \geq 0$ response to a time 0 news shock to agency purchases. Expected agency purchases are proxied by agency net purchases made over the next half a year. As in Fieldhouse, Mertens and Ravn (2018), to address endogeneity, we use the indicator of non-cyclical policy events, deflated by the core PCE price index and scaled by trend originations $X_{t}$, as the instrument.

To make the results comparable to Fieldhouse, Mertens and Ravn (2018), we use the same set of control variables $Z_{t}$ (converted to quarterly values). These are the lagged growth rates of the core PCE price index, a nominal house price index, and total mortgage debt, the log level of real mortgage originations, housing starts, and lags of several interest rate variables: the 3-month T-bill rate, the 10-year Treasury rate, the conventional mortgage interest rate, and the BAA-AAA corporate bond spread. They also include lags of agency net purchases and commitments as a ratio of $X_{t}$ as well as the unemployment rate and the growth rate of real personal income. See Appendix A for a detailed description of the data sources and definitions.

\subsection{Measuring Expenditure Data}

We use households' expenditure on non-durable goods and services as a response variable $y_{t}$ in equation (2). To construct our measure of expenditure we use the interview section of the Consumer Expenditure Survey (CEX) between 1980 and 2007. ${ }^{3}$ We define non-durable goods and services as food, alcohol, tobacco, fuel, light and power, clothing and footwear, personal goods and services, fares, leisure services, household services, nondurable household goods, motoring expenditure, and leisure goods. We adjust the food at home between 1982 and 1987 following Aguiar and Bils (2015). We also define households' income as an amount of income before tax in the past 12 months. After 2005, BLS started imputing missing income observations. Before 2004 we impute missing income observations as in Coibion et al. (2017). We exclude households that are in either top 1\% or bottom $1 \%$ of either the non-durable expenditure or income level. We also exclude households that report zero food expenditure. Finally, we exclude households whose household head is below 25 and over 74 years old. We also keep the households that do not change the housing tenure status between the interviews.

\footnotetext{
${ }^{3}$ Data between 1980 and 1995 is obtained from ICPSR through UK Data Service. Post-1995 data is publicly available at the Bureau of Labor Statistics (BLS) website.
} 


\subsection{The Effect of Agency Purchases on Expenditure: Pseudo-Cohort Analysis}

In this section, we document the response of households' expenditure to shock to agency purchases. The timing is such that the shock can be treated as a news shock to net purchases made over the next half a year.

As documented by Fieldhouse, Mertens and Ravn (2018), an increase in mortgage purchases by the agencies boosts mortgage lending and lowers mortgage rates. It is, therefore, important to distinguish between those households who own the house with a mortgage and those without. In the long run, agency purchases also influence house prices and expand homeownership, therefore the effect on those households who own the house and those who do not might be different. The CEX survey, on top of containing rich income and expenditure data, contains information on housing tenure status. We utilize this information and group the households into three categories based on their tenure status in the spirit of Cloyne, Ferreira and Surico (2018). The categories are renters, mortgagors and outright owners. Unfortunately, given the rotating panel nature of the CEX survey, it is not possible to follow individual households for more than four quarters over which they are observed. We, therefore, employ a grouping estimator to aggregate individual observations into pseudo-cohorts by housing tenure as in Browning, Deaton and Irish (1985). One concern with this identification strategy is the endogenous switching between housing tenure status because of policy changes. In the CEX, we can track exactly the households that switch between the interviews. We find that a very small number of households actually do switch the status between the interviews. We run two estimations - one including the households who switch, and one excluding, and our results remain identical in both cases. Thus, for our main exercise, we exclude the switchers.

We then look at the response of households' expenditure, based on their housing tenure status, to a $1 \%$ increase in net purchases by the agencies, anticipated 2 quarters in advance, under the specification in (2) using the non-cyclically motivated narrative measure as an instrument. Figure 3 plots the coefficients $b_{h}$ from equation (2) over the horizon $h=1$ (one quarter) to $h=8$ (two years) along with $90 \%$ and $95 \%$ confidence intervals. We see from the figure, that after a news shock to agency net purchases the only group that significantly increases their expenditure are the mortgagors, for the horizon between three and seven quarters, while the change in expenditure for renters and owners is insignificant for all horizons. Moreover, a year after the shock we document a clear ranking 
of the responses: mortgagors react the most (about 0.03 basis points), followed by renters (about 0.015 basis points), and finally homeowners (close to zero).

Figure 3: Impulse response of expenditure to an additional to a $1 \%$ increase in net purchase by FNMA \& FHLMC, anticipated 2 quarters before. Blue areas and broken lines represent $90 \%$ and $95 \%$ confidence intervals, respectively.
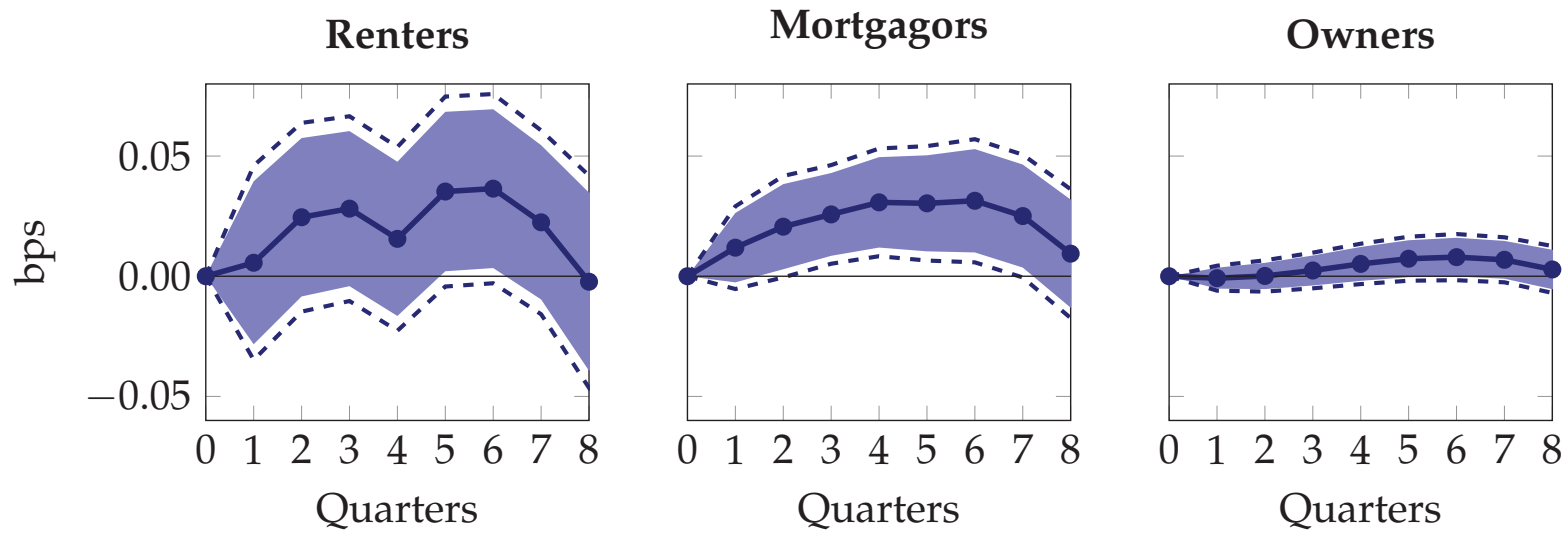

\subsection{Response of Expenditure Inequality}

In Section 2 we documented the evidence that following a news shock to agency purchase activities there is a heterogeneous response between housing tenure groups. We now look at what happens with expenditure within each of the groups. For that, we construct a Gini coefficient of the level of expenditure on non-durable goods and services in the spirit of Coibion et al. (2017). Our measure of inequality is raw: we do not control for any household characteristics (number of household members, age, education). The only control characteristic that we take is the housing tenure status.

Figure 4 plots the response of the Gini coefficient (measured between 0 and 100) to a $1 \%$ increase in net purchases by agencies, anticipated 2 quarters before. The top left panel plots the response of the Gini coefficient to a news shock for all the households in the data. We can see the positive and significant increase (at 90\% significance level) in expenditure inequality one quarter after the shock by about a quarter of percentage point. Expenditure inequality within the renters' group (top right panel) does not respond significantly. We can neither see a significant increase in expenditure inequality within the homeowners' group (bottom right panel). With regards to expenditure inequality within the mortgagor group (bottom left panel), there is a positive and significant (both at $90 \%$ and $95 \%$ significance level) increase of inequality by almost half percentage point. This suggests that an overall increase in expenditure inequality is mostly driven by an increase within 
the mortgagors. In the next section, we will analyze what characteristics of households (depending on their income level and their housing tenure status) and of mortgagors in particular (depending on the length of their mortgage) drives the heterogeneous response of expenditure and expenditure inequality between the three groups of households.

Figure 4: Impulse response of expenditure Gini to a 1\% increase in net purchase by FNMA \& FHLMC, anticipated 2 quarters before. Blue areas and broken lines represent $90 \%$ and $95 \%$ confidence intervals, respectively.
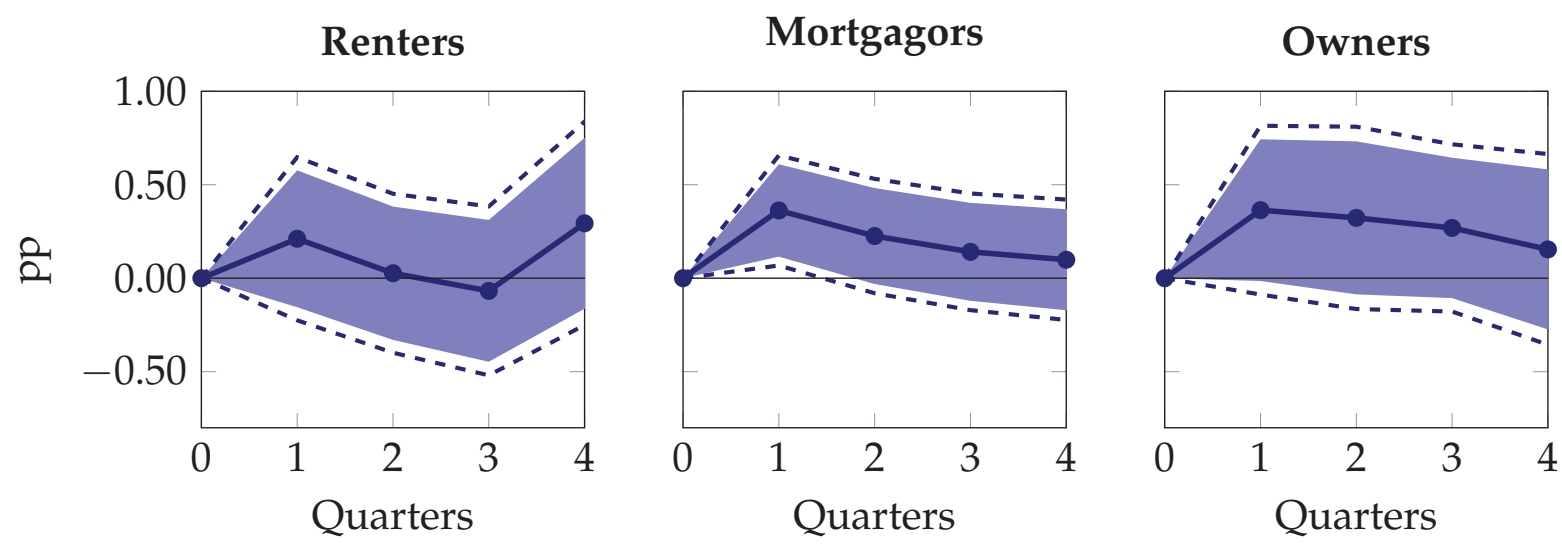

\section{A Life-Cycle Model with Housing Markets}

In the previous section, we documented the causal effect of news shock to agency mortgage purchases. Unfortunately, with the data available it is not possible to exactly identify the transmission mechanism through which the effects work. To understand which channel is exactly responsible for an increase in expenditure for mortgagors only, and increase in the inequality for that group, in this section we develop a Huggett (1996) type of heterogeneous agent life-cycle model with uninsurable risk, endogenous housing choice, and aggregate mortgage market shocks (see Sommer and Sullivan (2018); Kaplan, Mitman and Violante (2018); Wong (2019)). Through the lens of this model, we explain the empirical evidence we found in the previous sections and analyze which channels contribute to the results indicated.

\subsection{Demographics, Preferences and Labor Income}

Demographics Time is discrete. Economy is populated by a continuum of finitely-lived households. Age is indexed by $j=1, \ldots, J$. Households work for first $J_{r}-1$ periods and are retired until period $J$. Life span is certain and all households die with certainty at age $J$. 
Preferences Households maximize expected lifetime utility is given by

$$
\mathbb{E}_{0}\left[\sum_{j=1}^{J} \beta^{j-1} u\left(c_{j}, s_{j}\right)+\beta^{J} v\left(a_{J}\right)\right],
$$

Here $c_{j}$ denotes the consumption of goods at age $j$ and $s_{j}$ denotes the consumption of housing services at age $j, \beta$ is the discount factor and $a_{J}$ is the amount of bequest left my a household of age $J$. The only source of uncertainty in the economy is the idiosyncratic income shock (described below). Utility function $u$ is a CES aggregator over consumption and housing

$$
u(c, s)=\frac{\left[(1-\phi) c^{1-\gamma}+\phi s^{1-\gamma}\right]^{\frac{1-\vartheta}{1-\gamma}}-1}{1-\vartheta}
$$

while the bequest function $v$ is given as in De Nardi (2004)

$$
v(a)=\psi \frac{(a+\underline{a})^{1-\vartheta}-1}{1-\vartheta}
$$

where $\phi$ denotes housing preference, $1 / \gamma$ is the elasticity of substitution between nondurable consumption and housing services, $1 / \vartheta$ is the IES, $\psi$ measures the strength of bequest motive while $\underline{a}$ measures how luxurious is the bequest.

Labor Income Working-age households receive exogenous income $y_{j}$ given by

$$
y_{j}=\chi_{j} \exp \left(\epsilon_{j}\right)
$$

$\chi_{j}$ is the deterministic age profile and $\epsilon_{j}$ is the idiosyncratic component that follows firstorder Markov process. After retirement, households receive social security benefits

$$
y_{j}=\rho_{s s} y_{J_{r}}, \quad j>J_{r}
$$

where $\rho_{S S}$ is a replacement rate and $y_{J_{r}}$ are their earnings in the last working period. ${ }^{4}$ The pay as you go social security system is run by the government. Finally, let $Y_{j}$ denote the age-dependent transition of earning from age $j$ to age $j+1$ conditional on income $y_{j}$.

\subsection{Housing}

Households can either rent or own the house. Houses are characterized by their size, which is given by a discrete set. Let $\widetilde{\mathcal{H}}$ denote the set of houses available for rent, while $\mathcal{H}$

\footnotetext{
${ }^{4}$ To reduce the numerical burden, we only keep track of last-period's income to determine household's pension. Alternatively, at a cost of increasing the state space in the model we can include the whole history of income.
} 
denotes the set of owner-occupied houses. We assume that the price of the house is fixed and is equal to $p_{h}$ while the rental price of a housing unit is denoted by $\rho_{h}$, which is equal to a fixed fraction of house price.

To distinguish house owners from house renters, we assume that housing generates service flow equal to the size of the house, i.e. $s=\tilde{h}$, where $\tilde{h} \in \widetilde{\mathcal{H}}$, while owning a house generates an extra utility for the household, such that $s=\omega h$, where $\omega>1$ and $h \in \mathcal{H}$.

Every period the homeowner has to pay the maintenance cost $\delta_{h} p_{h} h$ that fully offsets physical depreciation of the house, and tax $\operatorname{cost} \tau_{h} p_{h} h$. There is a transaction cost equal to $\kappa_{h} p_{h} h$ associated with buying or selling the house. There is no transaction cost for renting.

\subsection{Assets, Mortgages and Market Arrangements}

Liquid Assets Households can save in one-period bonds, $a$, with a exogenous interest rate given by $r_{a}$. Households are not allowed any unsecured borrowing and their borrowing constraint is given by

$$
a \geq 0
$$

Let $q_{a}$ denote the price of bond, such that $q_{a}=1 /\left(r_{a}+1\right)$

Mortgages House purchase can be financed by a mortgage. A household that takes out a new mortgage with a principal balance $m^{\prime}$ receives from a lender $q_{m} m^{\prime}$ units of the numeraire good. The mortgage price $q_{m}$ is fixed and is such that $q_{m}<1$. We assume that all mortgages are long-term, subject to interest rate $r_{m}$ and have to be repaid over the remaining working life of the borrower. We assume that mortgage rate $r_{m}$ is given by

$$
r_{m}=(1+\iota) r_{a}
$$

where $\iota$ controls the spread between $r_{a}$ and $r_{m}$. Down-payment for a borrower who takes out a mortgage of size $m^{\prime}$ to buy a house of size $h^{\prime}$ is

$$
p_{h} h^{\prime}-q_{m} m^{\prime}
$$

Mortgage origination is also subject to a fixed origination cost $\kappa_{m}$. When taking out a mortgage, households have to satisfy two constraints. The first one is the maximum loanto-value constraint: the initial mortgage size must be less than a fraction $\lambda_{m}$ of the value of the house being purchased

$$
m^{\prime} \leq \lambda_{m} p_{h} h^{\prime}
$$


The second constraint is the maximum payment-to-income constraint: the first minimum mortgage payment must be less than a fraction $\lambda_{\pi}$ of the income at time of purchase

$$
\pi_{j}^{\min }\left(m^{\prime}\right) \leq \lambda_{\pi} y_{j}
$$

where we define the minimum payment function $\pi_{j}^{\min }\left(m^{\prime}\right)$ using a constant amortization formula

$$
\pi_{j}^{m i n}\left(m^{\prime}\right)=\frac{r_{m}\left(1+r_{m}\right)^{J_{r}-j}}{\left(1+r_{m}\right)^{J_{r}-j}-1} m^{\prime}
$$

that assumes that the borrower is required to make $J_{r}-j$ payments $\pi$ that exceed minimum payment requirement after mortgage origination. Retired households are not allowed to take out a mortgage, but they can buy a house out of savings. The remaining mortgage principle evolves according to

$$
m^{\prime}=m\left(1+r_{m}\right)-\pi
$$

We also assume that households are allowed to refinance the existing mortgage. When refinancing (taking out a new mortgage), households have to repay the existing mortgage balance, pay the fixed mortgage origination cost, and satisfy both loan-to-value and payment-to-income constraints. Households are also allowed to sell the house, given that they repay the remained of the mortgage as well as transaction costs. Finally, households can default on the mortgage, if they cannot satisfy the minimum payment requirement. Households that choose to default incur the utility cost of $\xi$ and are forced to rent the smallest available dwelling that period.

\subsection{Government}

In the model, government receives revenues from the property tax $\tau_{h}$ and progressive income tax $\mathcal{T}(y, m)$ that depends on income $y$ and mortgage holdings $m$. Interest payed on mortgages is deductable up to a predetermined threshold. We assume that tax function is progressive as in Heathcote, Storesletten and Violante (2017) and $\mathcal{T}$ takes the form

$$
\mathcal{T}(y, m)=y-\tau_{y}^{0}\left(y-r_{m} \min \{m, \bar{m}\}\right)^{1-\tau_{y}^{1}}
$$

where $\tau_{y}^{0}$ and $\tau_{y}^{1}$ measure the progressivity of the tax system and $\bar{m}$ denotes the maximum allowed deductible mortgage. On the spending side, the government finances social security system for the households. The government runs a balanced budget, with services 
$G$ (not valued by the household) adjusting to absorb any difference between government income and spending.

\subsection{Dynamic Problem of the Household}

We now describe the dynamic problem of households. There are two types of households in the economy: homeowners and non-homeowners. Let $V_{j}^{n}$ denote the value function of non-homeowner at age $j$ and let $V_{j}^{h}$ denote the value function of the homeowner at age $j$. When non-homeowner enters the economy at age $j$ he has two choices - either remain non-homeowner in the next period (rent a house) or become a homeowner next period (buy a house). Let $V_{j}^{r}$ and $V_{j}^{o}$ denote the value function of renters and buyers, respectively. Non-homeowners essentially solve the following problem

$$
V_{j}^{n}\left(\mathbf{x}_{j}^{n}\right)=\max \left\{V_{j}^{r}\left(\mathbf{x}_{j}^{n}\right), V_{j}^{o}\left(\mathbf{x}_{j}^{n}\right)\right\}
$$

where $\mathbf{x}_{j}^{h}$ denotes the vector of state variables of the non-homeowner, described below. When home-owner enters the economy he has four different choices. He can either continue paying the existing mortgage (let $V_{j}^{p}$ denote the value function of the mortgage payer), repay the existing mortgage and get a new mortgage (let $V_{j}^{f}$ denote the value function of the mortgage refinancer), repay the remaining mortgage and sell the house (let $V_{j}^{s}$ denote the value function of the seller) or default on the mortgage payments (let $V_{j}^{d}$ denote the value function of mortgage payer who defaults). Every period, the homeowner solves the following problem

$$
V_{j}^{h}\left(\mathbf{x}_{h}\right)=\max \left\{V_{j}^{p}\left(\mathbf{x}_{j}^{h}\right), V_{j}^{f}\left(\mathbf{x}_{j}^{h}\right), V_{j}^{S}\left(\mathbf{x}_{j}^{h}\right), V_{j}^{d}\left(\mathbf{x}_{j}^{h}\right)\right\}
$$

where $\mathbf{x}_{j}^{h}$ denotes the vector of state variables of the homeowner, described below.

Non-homeowners of age $j$ enter the period with holding of liquid assets $a_{j}$ and exogenous income $y_{j}$. Homeowners of age $j$, on the other hand, also enter the period with outstanding balance on the mortgage $m$ and house $h$. When $m>0$ we refer to homeowners as the mortgagor, whereas when $m=$ we refer to them as outright owners. Thus

$$
\begin{aligned}
\mathbf{x}_{j}^{n} & =\left(a_{j}, y_{j}\right) \\
\mathbf{x}_{j}^{h} & =\left(a_{j}, m_{j}, h_{j}, y_{j}\right)
\end{aligned}
$$

We now describe in detail the problem of each household in a recursive form. From here on the state and control variables with no subscript denote the current age/period vari- 
ables, i.e. $a_{j}=a$, while state and control variables with ' superscript denote the next period/age variables, i.e. $a_{j+1}=a^{\prime}$.

Renters The households of age $j$ that enter the period as non-homeowners and decide to rent next period, choose the level of consumption today $(c)$, the level of liquid savings next period $\left(a^{\prime}\right)$ and the size of the rented dwelling for the next period $\left(\tilde{h}^{\prime}\right)$. In recursive form, their problem can be written as

$$
V^{r}\left(\mathbf{x}^{n}\right)=\max _{c, a^{\prime}, \tilde{h}^{\prime}} u(c, s)+\beta \mathbb{E}_{\epsilon^{\prime}}\left[V^{n^{\prime}}\left(\mathbf{x}^{n^{\prime}}\right)\right]
$$

Renters solve the above problem subject to:

$$
\begin{aligned}
& c+\rho_{h} \tilde{h}^{\prime}+q_{a} a^{\prime} \leq a+y-T(y, 0) \\
& a^{\prime} \geq 0 \\
& s=\tilde{h}^{\prime}, \quad \tilde{h}^{\prime} \in \widetilde{\mathcal{H}} \\
& y^{\prime} \sim Y(y)
\end{aligned}
$$

where the equations above are budget constraint, borrowing constraint, housing services production and income evolution, respectively. Let $\mathbb{1}^{r}\left(\mathbf{x}^{n}\right)$ denote the decision of nonhomeowner with state variables $\mathbf{x}^{n}$ to rent a house.

Buyers The households of age $j$ that enter the period as non-homeowners and decide to buy a house, choose the level of consumption today $(c)$, the level of liquid savings next period $\left(a^{\prime}\right)$, the size of the house to buy $\left(h^{\prime}\right)$, and the level of mortgage to take out. In recursive form, their problem can be written as

$$
V^{o}\left(\mathbf{x}^{n}\right)=\max _{c, a^{\prime}, h^{\prime}, m^{\prime}} u(c, s)+\beta \mathbb{E}_{\epsilon^{\prime}}\left[V^{h^{\prime}}\left(\mathbf{x}^{h^{\prime}}\right)\right]
$$

Renters solve the above problem subject to:

$$
\begin{aligned}
& c+q_{a} a^{\prime}+p_{h} h^{\prime}+\kappa_{m} \leq a+y-T(y, 0)+q_{m} m^{\prime} \\
& m^{\prime} \leq \lambda_{m} p_{h} h^{\prime} \\
& \pi^{\min }\left(m^{\prime}\right) \leq \lambda_{\pi} y \\
& a^{\prime} \geq 0 \\
& s=\omega h^{\prime}, \quad h^{\prime} \in \mathcal{H} \\
& y^{\prime} \sim Y(y)
\end{aligned}
$$


where the equations are the budget constraint, LTV constraint, PTI constraint, borrowing constraint, housing services production, and income evolution, respectively. Let $\mathbb{1}^{o}\left(\mathbf{x}^{n}\right)$ denote the decision of non-homeowner with state variables $\mathbf{x}^{n}$ to buy a house, with

$$
\mathbb{1}^{r}\left(\mathbf{x}^{n}\right)+\mathbb{1}^{o}\left(\mathbf{x}^{n}\right)=1
$$

Mortgage payers The households of age $j$ that enter the period as homeowners with a given level of mortgage $m$ and house size $h$, and decide to make the payment towards the mortgage balance, choose the level of consumption today $(c)$, the level of liquid savings next period $\left(a^{\prime}\right)$, and the size of payment $(\pi)$. In recursive form, their problem can be written as

$$
V^{p}\left(\mathbf{x}^{h}\right)=\max _{c, a^{\prime}, \pi} u(c, s)+\beta \mathbb{E}_{\epsilon^{\prime}}\left[V^{h^{\prime}}\left(\mathbf{x}^{h^{\prime}}\right)\right]
$$

Mortgage payers solve the above problem subject to:

$$
\begin{aligned}
& c+q_{a} a^{\prime}+\left(\delta_{h}+\tau_{h}\right) p_{h} h^{\prime}+\pi \leq a+y-T(y, m) \\
& m^{\prime}=\left(1+r_{m}\right) m-\pi \\
& \pi \geq \pi^{\min }(m) \\
& a^{\prime} \geq-\lambda_{a} p_{h} h \\
& s=\omega h^{\prime}, \quad h^{\prime}=h \in \mathcal{H} \\
& y^{\prime} \sim Y(y)
\end{aligned}
$$

where the equations are the budget constraint, mortgage balance evolution, minimum payment requirement, borrowing constraint, housing services production, and income evolution, respectively. When choosing the current level of mortgage payment, the household need to satisfy minimum payment requirement. This constraint is similar to the PTI requirement on origination (equation), but does not limit household making payments out of the income only (for example, a household that received a negative income shock can still make a mortgage payment by using some of the assets). Let $\mathbb{1}^{p}\left(\mathbf{x}^{h}\right)$ denote the decision of homeowner with state variables $\mathbf{x}^{p}$ to make a payment towards the mortgage.

Mortgage refinancers The households of age $j$ that enter the period as homeowners with a given level of mortgage $m$ and house size $h$, and decide to refinance the existing mortgage, choose the level of consumption today $(c)$, the level of liquid savings next period 
$\left(a^{\prime}\right)$, and the level of new mortgage $\left(m^{\prime}\right)$. In recursive form, their problem can be written as

$$
V^{f}\left(\mathbf{x}^{h}\right)=\max _{c, a^{\prime}, m^{\prime}} u(c, s)+\beta \mathbb{E}_{\epsilon^{\prime}}\left[V^{h^{\prime}}\left(\mathbf{x}^{h^{\prime}}\right)\right]
$$

Mortgage refinancers solve the above problem subject to:

$$
\begin{aligned}
& c+q_{a} a^{\prime}+\left(\delta_{h}+\tau_{h}\right) p_{h} h^{\prime}+\left(1+r_{m}\right) m+\kappa_{m} \leq a+y-T(y, m)+q_{m} m^{\prime} \\
& m^{\prime} \leq \lambda_{m} p_{h} h^{\prime} \\
& \pi^{\min }\left(m^{\prime}\right) \leq \lambda_{\pi} y \\
& a^{\prime} \geq-\lambda_{a} p_{h} h \\
& s=\omega h^{\prime}, \quad h^{\prime}=h \in \mathcal{H} \\
& y^{\prime} \sim Y(y)
\end{aligned}
$$

where the equations are the budget constraint, mortgage balance evolution, PTI constraint, borrowing constraint, housing services production, and income evolution, respectively. Let $\mathbb{1}^{f}\left(\mathbf{x}^{h}\right)$ denote the decision of homeowner with state variables $\mathbf{x}^{p}$ to refinance the existing mortgage.

Sellers The households of age $j$ that enter the period as homeowners with a given level of mortgage $m$ and house size $h$, and decide to sell their house in the current period, choose the level of consumption today $(c)$, the level of liquid savings next period $\left(a^{\prime}\right)$ and the size of the rented dwelling for the next period $\left(\tilde{h}^{\prime}\right)$, as they will remain non-homeowners for the following period.

$$
V^{s}\left(\mathbf{x}^{n}\right)=\max _{c, a^{\prime}, \tilde{h}^{\prime}} u(c, s)+\beta \mathbb{E}_{\epsilon^{\prime}}\left[V^{n^{\prime}}\left(\mathbf{x}^{n \prime}\right)\right]
$$

House sellers solve the above problem subject to:

$$
\begin{aligned}
& c+\rho_{h} \tilde{h}^{\prime}+q_{a} a^{\prime} \leq a_{s}+y-T(y, m) \\
& a^{\prime} \geq 0 \\
& s=\tilde{h}^{\prime}, \quad \tilde{h}^{\prime} \in \widetilde{\mathcal{H}} \\
& y^{\prime} \sim Y(y)
\end{aligned}
$$

where $a_{s}$ denotes the current level of assets plus the proceedings from selling the house net of transaction costs and mortgage balance, given by

$$
a_{s}=a+\left(1-\delta_{h}-\tau_{h}-\kappa_{h}\right) p_{h} h-\left(1+r_{m}\right) m
$$


Let $\mathbb{1}^{s}\left(\mathbf{x}^{h}\right)$ denote the decision of homeowner with state variables $\mathbf{x}^{p}$ to sell the house.

Defaulters The households of age $j$ that enter the period as homeowners with a given level of mortgage $m$ and house size $h$, might decide to default on their mortgage if they aren't able to make the minimum payment towards the mortgage balance. If they default, they choose the level of consumption today $(c)$ and the level of liquid savings next period $\left(a^{\prime}\right)$; to prevent the strategic default in the model, the households that default are forced to rent the minimum dwelling available for renting and are not allowed to buy a house for another period. Computationally, this gives us more flexibility of controling the level of defaults in the model. In recursive form, their problem can be written as

$$
V^{d}\left(\mathbf{x}^{n}\right)=\max _{c, a^{\prime}, \tilde{h}^{\prime}} u(c, s)-\zeta+\beta \mathbb{E}_{\epsilon^{\prime}}\left[V^{n^{\prime}}\left(\mathbf{x}^{n^{\prime}}\right)\right]
$$

where $\zeta$ denotes the utility penalty. Defaulters solve the above problem subject to:

$$
\begin{aligned}
& c+\rho_{h} \tilde{h}_{\text {min }}+q_{a} a^{\prime} \leq a+y-T(y, 0) \\
& a^{\prime} \geq 0 \\
& s=\tilde{h}_{\text {min }}, \quad \tilde{h}_{\text {min }} \in \arg \min \widetilde{\mathcal{H}} \\
& y^{\prime} \sim Y(y)
\end{aligned}
$$

Let $\mathbb{1}^{d}\left(\mathbf{x}^{h}\right)$ denote the decision of homeowner with state variables $\mathbf{x}^{p}$ to default on the mortgage, with

$$
\mathbb{1}^{p}\left(\mathbf{x}^{h}\right)+\mathbb{1}^{f}\left(\mathbf{x}^{h}\right)+\mathbb{1}^{s}\left(\mathbf{x}^{h}\right)+\mathbb{1}^{d}\left(\mathbf{x}^{h}\right)=1
$$

\subsection{Definition of Equilibrium}

Our definition of equilibrium consists of households' consumption decision rules

$$
\left\{c^{r}\left(\mathbf{x}^{n}\right), c^{o}\left(\mathbf{x}^{n}\right), c^{p}\left(\mathbf{x}^{h}\right), c^{f}\left(\mathbf{x}^{h}\right), c^{s}\left(\mathbf{x}^{h}\right), c^{d}\left(\mathbf{x}^{h}\right)\right\}
$$

savings decision rules

$$
\left\{a^{r}\left(\mathbf{x}^{n}\right), a^{o}\left(\mathbf{x}^{n}\right), a^{p}\left(\mathbf{x}^{h}\right), a^{f}\left(\mathbf{x}^{h}\right), a^{\mathcal{S}}\left(\mathbf{x}^{h}\right), a^{d}\left(\mathbf{x}^{h}\right)\right\}
$$

mortgage decision rules

$$
\left\{m^{o}\left(\mathbf{x}^{n}\right), m^{f}\left(\mathbf{x}^{h}\right), \pi\left(\mathbf{x}^{h}\right)\right\}
$$

and housing choice rules

$$
\left\{\tilde{h}^{r}\left(\mathbf{x}^{n}\right), h^{o}\left(\mathbf{x}^{n}\right), h^{p}\left(\mathbf{x}^{h}\right), h^{f}\left(\mathbf{x}^{h}\right), \tilde{h}^{s}\left(\mathbf{x}^{h}\right)\right\}
$$


and government expenditure $G$, such that

1. Households' policy function solve problems (20), (22), (24), (26), (28) and (31) given prices $p_{h}$ and $\rho_{h}$

2. Government expenditure $G$ clears governmental budget constraint

3. Supply of owner-occupied housing is fixed at some level $\widehat{H}$. The price of housing $p_{h}$ is such that in equilibrium, the demand for owner-occupied housing (which consists of new houses bought, existing housing of mortgage payer minus housing of sellers and defaulters) is equal to the supply. Similarly, $\rho_{h}$ is determined by the equilibrium conditions in the rental market.

We next describe the value of the model parameters that we use to calculate the equilibrium.

\section{Parametrization}

The model calibrated at annual frequency. We set the parameters of the model to income and wealth moments from the 2001 wave of SCF. A subset of parameters are set exogenously without the need to solve for the steady-state of model. The target modelimplied and data moments are reported in Table 1.

Table 1: Targeted moments in the parametrization

\begin{tabular}{lcc}
\hline \multicolumn{3}{c}{ Targeted Moments } \\
Moment & Model Value & Empirical Value \\
\hline Net worth to income ratio & 5.8 & 5.5 \\
Ratio of net worth $75 / 50$ & 1.6 & 1.5 \\
Homeownership rate & 0.63 & 0.66 \\
Default rate & 0.002 & 0.005 \\
House size of owners to renters & 1.5 & 1.5 \\
\hline
\end{tabular}

Demographics and Preferences The model period is one year. Households enter the economy in age 21, retire at age 65 and live until age 81. This corresponds to $J_{r}=44$ and $J=60$. We use Piazzesi, Schneider and Tuzel (2007) to set the elasticity of substitution between consumption and housing services is set to 1.25 (corresponding to $\gamma=0.8$ ). We 
use the same strategy as Kaplan, Mitman and Violante (2018) set risk aversion parameter $\vartheta$ equal to 2 so that the EIS is 0.5 The properties of the baseline model are robust to change in $\vartheta$ as long as EIS is less than 1. The discount factor $\beta$ is set equal to 0.964 , implying the average net worth to income ratio of 5.8, slightly above empirical value of 5.5 from SCF. To control to which extent bequest is perceived as luxury good, we set $\underline{a}=7.7$. The strength of the bequest motive is controlled by $\psi$, which we set equal to match the ratio of net worth at age 75 to net worth at age 50 (to proxy the importance of bequests as a saving motive). For $\psi$ equal to 7 , the model-implied ratio is 1.6 , compared to 1.5 in the SCF. The extra utility from owned housing, $\omega$, is set to be equal to 1.015, to match the average homeownership rate. The model-implied homeownership rate is 63 percent compared to 66 percent in the data. The dis-utility from defaulting, $\zeta$, is set equal to 5 . The modelimplied default rate is about 0.2 percent, compared 0.5 percent in the data. Finally, we set the share of utility from housing $\phi$ equal to 0.16 , that matches the share of housing in total consumption expenditure in NIPA. These are summarized in Table 2.

Table 2: Parameter values (demographics and preferences)

\begin{tabular}{llc}
\hline \multicolumn{2}{c}{ Demographics and Preferences } \\
\hline$J$ & Length of life & 60 \\
$J_{r}$ & Working life & 44 \\
$\gamma$ & 1/EIS & 0.8 \\
$\vartheta$ & Risk aversion & 2 \\
$\beta$ & Discout factor & 0.964 \\
$\underline{a}$ & Bequest as luxury & 7.7 \\
$\psi$ & Strength of bequest & 7 \\
$\omega$ & Utility from homeownership & 1.015 \\
$\zeta$ & Disutility from default & 5 \\
$\phi$ & Share of housing in utility & 0.16 \\
\hline
\end{tabular}

Labor Income and Government Expenditure The deterministic and stochastic component of labor earnings, $\chi_{j}$, is calculated using the data on labor earnings from 2001 wave of the SCF. We set the social security replacement rate to 60 percent. The parameters of the tax function (15), $\tau_{y}^{0}$ and $\tau_{y}^{1}$, are set to 0.75 and 0.151 , respectively and is taken from Heathcote, Storesletten and Violante (2017) for the US. Parameter $\tau_{y}^{0}$ measures the average level of taxation and parameter $\tau_{y}^{1}$ measures the degree of progressivity. The maximum level of tax-deductible mortgage, $\bar{m}$, is set to correspond to $\$ 1$ million. The property tax 
$\tau_{h}$ is set to 1 percent, which is the median tax rate across the US. These are summarized in Table 3.

Table 3: Parameter values (labor income and government expenditure)

\begin{tabular}{llc}
\hline \multicolumn{2}{c}{ Labor Income and Government Expenditure } \\
\hline$\chi_{j}$ & Deterministic life-cycle profile & - \\
$\tau_{y}^{0}$ & Income tax parameter & 0.75 \\
$\tau_{y}^{1}$ & Income tax parameter & 0.151 \\
$\rho_{s S}$ & Replacement rate & 0.6 \\
$\bar{m}$ & Mortgage deduction limit & $20^{*}$ \\
$\tau_{h}$ & Property tax & 0.01 \\
\hline
\end{tabular}

${ }^{*}$ A unit of the final good corresponds to $\$ 50000$, which is the median income in the 2001 wave in SCF.

Housing We fix the grid for the owner-occupied houses $(\mathcal{H})$ and rented houses $(\widetilde{\mathcal{H}})$, so that households are only allowed to choose to buy or rent of the dwellings from the grid. The minimum size of the owner-occupied dwelling is set to 1.5 to represent the ratio of the average house size of owners to renters (Chatterjee and Eyigungor, 2015). The depreciation rate of housing is set equal to 1.5 percent. Transaction cost of selling the house, $\kappa_{h}$, is set to 8 percent, which is the average value reported in Quigley (2002). These are summarized in Table 4.

Liquid Assets and Mortgages We set the interest rate $r_{a}$ exogenously equal to 3 percent, and the spread parameter $\iota$ equal to 33 percent. This implies the mortgage rate $r_{m}$ of about 4 percent. The spread is set to match the observed difference between the average rate on 30-year fixed-term mortgages (series MORTGAGE30US from FRED) and the 10year T-Bill rate (series GS10) in 2001. The implied price of bond, $q_{a}$ is equal to 0.97 . The mortgage origination cost, $\kappa_{m}$, is set to equivalent of $\$ 2000$, corresponding to the sum of application, attorney, appraisal and inspection fees (see Kaplan, Mitman and Violante (2018)). The minimum down payment requirement $q_{m}$ is set to 15 percent and controls the overall market tightness. This number is consistent with recent estimates by Sommer and Sullivan (2018) and Kaplan, Mitman and Violante (2018). These are summarized in Table 4. 
Table 4: Parameter values (liquid assets and mortgages)

\begin{tabular}{llc}
\hline \multicolumn{2}{c}{ Housing, Liquid Assets and Mortgages } \\
\hline$\delta_{h}$ & Depreciation rate & 0.015 \\
$\kappa_{h}$ & Transaction cost & 0.08 \\
$r_{a}$ & Interest rate & 0.03 \\
$\iota$ & Spread & 0.33 \\
$r_{m}$ & Mortgage rate & 0.04 \\
$q_{a}$ & Price of bond & 0.97 \\
$\kappa_{m}$ & Mortgage origination cost & $0.04^{*}$ \\
$\lambda_{a}$ & Maximum borrowing limit & 0 \\
$q_{m}$ & Down payment requirement & 0.15 \\
\hline
\end{tabular}

${ }^{*}$ A unit of the final good corresponds to $\$ 50000$, which is the median income in the 2001 wave in SCF.

\subsection{Properties of the Baseline Model}

In this subsection we describe the life-cycle properties of the baseline model with parametrization specified in Tables 2-4. Figure 5 displays the lifetime profiles for several key model variables. Panel A plots the mean labor and pension income (solid black line) and non-durable consumption (dashed black line). Households increase their consumption until about age 30 and then keep it constant until the end of the lifetime. Panel B displays the mean lifetime savings profile of the households. As the households have the bequest motive - they do not dis-save towards the end of the lifetime and leave the portion of the savings as a bequest for the future generations. Panel C displays the mean mortgage balance in the economy. Households take out the mortgage later in life when they are about 30 years old so that the payment-to-income constraint (3.5) is satisfied. As the income is stochastic, some households do not take out the mortgage until later in life. Finally, Panel D displays the average homeownership rate in the economy (solid black line) to that of the data (broken red line). Some households (that receive good income shock early in life) buy a house early, while the others postpone the purchase until later in life. Households that had a sequence of bad income shocks towards the end of the lifetime sell their house and choose to rent instead, and use the selling proceedings to smooth consumption and leave the remainder towards bequest. The model matches well the general shape of homeownership over the life-cycle to that of the data (red broken line in Panel D). 
Figure 5: Mean life-cycle profiles in the baseline model. Panel A displays mean income (black solid line) and consumption (black dashed line). Panel B displays mean holdings of liquid asset. Panel C displays mean mortgage balance. Panel D displays mean homeownership rate in the model (black solid line) and in the data (red dotted line).

A. Income and Consumption

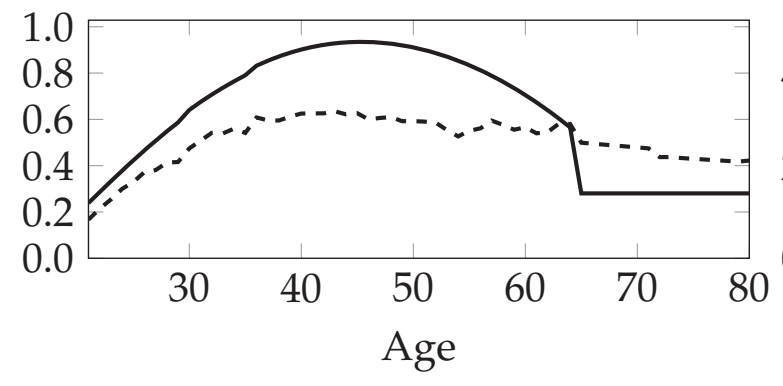

C. Mortgage

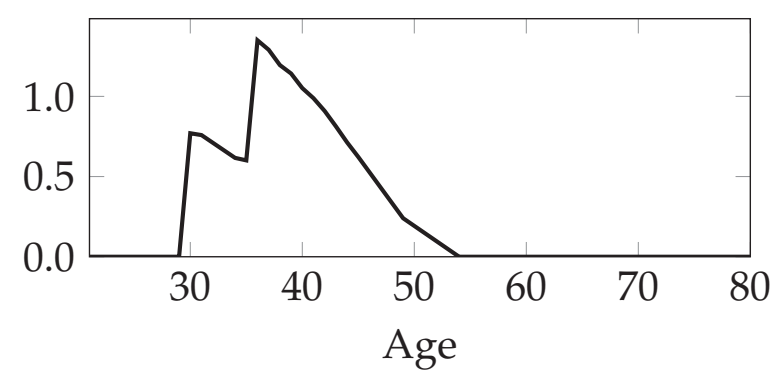

B. Liquid Assets

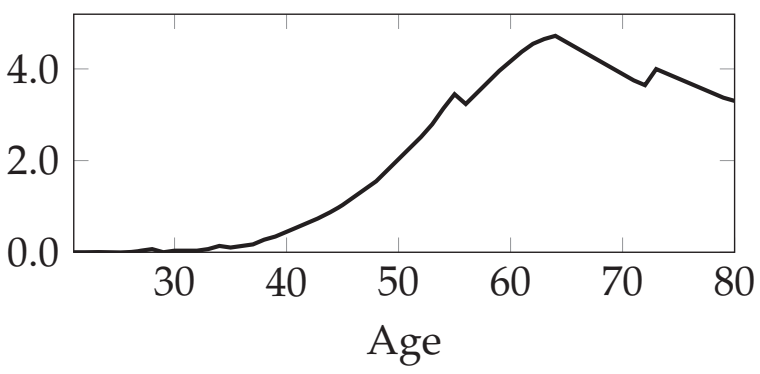

D. Homeownersip rate

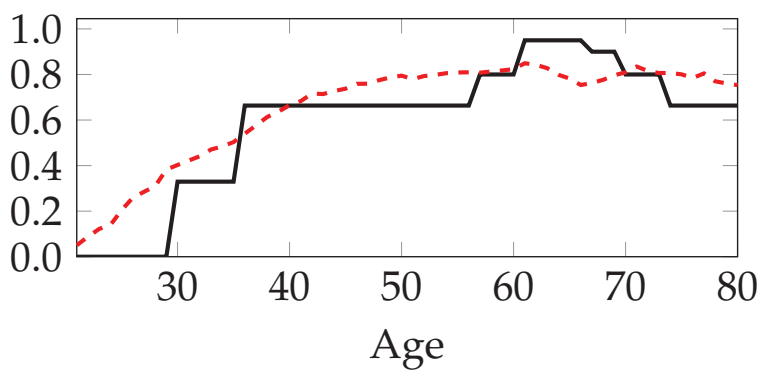

\section{Mortgage Market Intervention Experiment}

We next perform a mortgage market intervention experiment in the baseline model using the empirical evidence on the effects of governmental mortgage markets interventions on interest and mortgage rates.

\subsection{Macroeconomic Effects of Mortgage Market Intervention}

In their paper, Fieldhouse, Mertens and Ravn (2018) document the macroeconomic effects of news shock to agency mortgage purchases. They find that following a shock, the interest rates, as well as the mortgage rates, decrease, as does the spread between mortgage rates over the interest rates. Panels A and B in figure 6 plots the response of mortgage and interest rates, respectively. Panel $C$ in figure 6 plots the response of spread between the two along with one standard deviation confidence intervals. We see that interest and mortgage rates (panels $\mathrm{A}$ and $\mathrm{B}$ ) decline significantly immediately after the shock and remain low for at least two years. Spread between the two (panel C) declines significantly 3 quarters after the shock and remains negative for half a year. 
Figure 6: Impulse response of mortgage rate (Panel A), interest rate (Panel B), and spread (Panel $\mathrm{C}$ ) to an additional to a 1\% increase in net purchase by FNMA \& FHLMC, anticipated 2 quarters before.

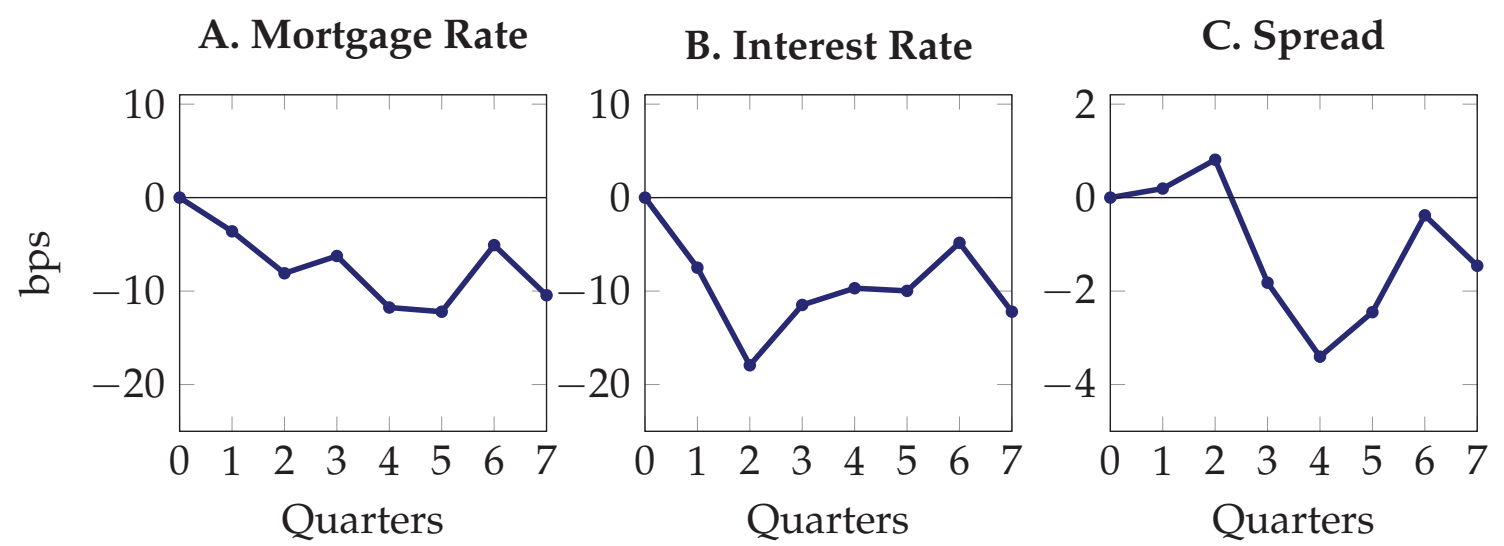

\subsection{Transitional Dynamics and Transmission Mechanism}

To understand the transmission mechanism through which mortgage market intervention operates, we perform the following policy experiment. Suppose that in period 0 the economy is in the steady state, where interest rates and mortgage rates are fixed, and so is the spread between the two. Between period 0 and period 1 (a year in the model), there is an exogenous intervention to the mortgage markets such that interest rate $r_{a}$ goes down. To account for the fact that empirical evidence suggests the drop in mortgage rates, as well as the drop in spreads, and using

$$
r_{m}=(1+\iota) r_{a}
$$

we also assume that spread parameter $\iota$ also declines. In period 1 , households enter the period with new interest and mortgage rates, and adjust their choice of consumption, mortgage balance, and liquid savings using the new policy functions. Figure 7 displays the simplified timeline of the policy experiment.

Figure 7: Timeline of the policy experiment

$\begin{array}{ccc}\text { Period 0: } & \text { Market Intervention: } & \text { Period 1: } \\ \text { economy in the SS } & r_{a} \downarrow, \iota \downarrow & \text { new policy functions }\end{array}$


We then analyze whether the policy experiment can reconcile the empirical evidence presented in section 2.4. Empirically, we found that exogenous intervention to mortgage markets makes households with the mortgage significantly increase their consumption expenditure, followed by a positive (but insignificant) increase in consumption expenditure of renters. The policy intervention has the smallest (and insignificant) increase in consumption expenditure for outright homeowners. We identify the same three groups of people in the model: renters (either renters that choose to rent, or homeowners that sell their house or default on the mortgage), mortgagors (either mortgagors who make payments towards positive mortgage balance or refinancers) and outright owners (household that own the house and have zero mortgage outstanding). We then calculate the change in consumption expenditures for these types of households. We report the results of the policy experiment in Table 5.

Table 5: Response of consumption expenditure to mortgage market intervention

\begin{tabular}{lc}
\hline Tenure & Change in Consumption \\
\hline Renters & $0.7 \mathrm{pp}$ \\
Mortgagors & $1.3 \mathrm{pp}$ \\
Outright Owners & $0.2 \mathrm{pp}$ \\
\hline
\end{tabular}

Following an exogenous change in the interest rate and spread parameter, the group that responds the most to policy change is the mortgagor group. After a cut in the interest and mortgage rates, they increase consumption by 1.3 percentage points. Renters also respond positively to change in the interest rates, increasing their consumption by 0.7 percentage points relative to initial steady state. Outright homeowners, on the other hand, react the least to the policy change and increase their consumption by only 0.2 percentage points.

Our second empirical result reported in Section 2.5 states that expenditure inequality increases significantly for mortgagors while there is no significant increase for the other two groups of households. To compare the empirical results with those of the model, we calculate the model-implied Gini coefficient before and after the policy experiment took place for all three groups of households. We then look at the change of the Gini coefficient after the policy. We report the results of the policy experiment in Table 6. 
Table 6: Response of expenditure Gini to mortgage market intervention

\begin{tabular}{lc}
\hline Tenure & Change in Gini \\
\hline Renters & $0.2 \mathrm{pp}$ \\
Mortgagors & $1.7 \mathrm{pp}$ \\
Outright Owners & $-0.1 \mathrm{pp}$ \\
\hline
\end{tabular}

Following an exogenous change in the interest rate and spread parameter, the expenditure Gini increases significantly for mortgagors. After a cut in the interest and mortgage rates, the consumption inequality measure increases by 1.7 percentage points. For renters and outright homeowners, the change in expenditure inequality is small, 0.2 and -0.1 percentage points, respectively. This response goes in line with the empirical evidence reported in Section 2.5.

We next analyze what is the transmission mechanism that policy operates through and what drives the increase in consumption reported in Table 5. The decrease in the interest rate has a straightforward effect on consumption of all households - as the interest rates drop, the opportunity cost of savings goes down and households choose to consume the extra income instead. For the outright homeowners (who are also older), both the low marginal propensity to consume as well as the bequest motive play the opposite role to that of the interest rates and as the result, they do not adjust their consumption. Both renters and mortgagors act like typical hand-to-mouth consumers: lowering the interest rate makes them save less and consume more. So why do mortgagors and renters react differently? The mortgage market intervention also affects the mortgage rate and the spread between the mortgage and interest rates. Mortgagors minimum payment requirement, given by equation (13), depends on the mortgage rate $r_{m}$. Lowering the rate $r_{m}$ (due to lowering in $r_{a}$ and $\iota$ ) relaxes the payment constraint for the mortgagors. So on top of the effect coming directly from lower interest rates, they also receive extra income from lower minimum payment. In the model, mortgagors utilize this by having access to refinancing: the benefit of refinancing coming from lower payments outweighs the fixed cost of refinancing, increasing the current level of wealth for the mortgagor group. Renters still observe an increase in consumption, but it's not as strong as that of the mortgagor group. Interestingly, we find that those renters that closer to buying mortgage increase consumption more relative to the households who take out the mortgage later one, implying there is some sort of anticipation effects present in the model. 


\section{Conclusions}

We study the heterogeneous impact of expansionary credit policies by combining exogenous policy changes in US federal housing agencies mortgage holdings with householdlevel data from the Consumer Expenditure Survey and the Survey of Consumer Finances. We group households into pseudo-cohorts based on their housing tenure status: renters, mortgagors, and homeowners. We show that following an increase in agency purchases, households with mortgage increase their spending, while outright homeowners and renters do not adjust their expenditure significantly. We explain this evidence through the lens of a Huggett (1996) type of heterogeneous life-cycle model with endogenous housing choice and idiosyncratic income risk. We calibrate the mortgage market intervention to be consistent with empirical macroeconomic evidence and show that the lower interest rate partially explains the small increase in expenditure of renters. We also show that low marginal propensity to consume and bequest motive outweighs the effect of a lower interest rate for outright homeowners Finally, and more importantly, we also show that lower mortgage rates as well as the change in spread between the rates generates mortgage refinancing motive and explains the high observed increase in expenditure for mortgagors. 


\section{References}

Aguiar, Mark, and Mark Bils. 2015. "Has consumption inequality mirrored income inequality?" The American Economic Review, 105(9): 2725-2756.

Auclert, Adrien. 2017. "Monetary Policy and the Redistribution Channel." National Bureau of Economic Research Working Paper 23451.

Bilbiie, Florin. 2017. “The New Keynesian Cross: Understanding Monetary Policy with Two Agents." mimeo.

Browning, Martin, Angus Deaton, and Margaret Irish. 1985. "A profitable approach to labor supply and commodity demands over the life-cycle." Econometrica, 503-543.

Chambers, Matthew, Carlos Garriga, and Don E Schlagenhauf. 2009. "Housing policy and the progressivity of income taxation." Journal of Monetary Economics, 56(8): 11161134.

Chatterjee, Satyajit, and Burcu Eyigungor. 2015. "A quantitative analysis of the US housing and mortgage markets and the foreclosure crisis." Review of Economic Dynamics, 18(2): 165-184.

Cloyne, James, Clodomiro Ferreira, and Paolo Surico. 2018. "Monetary policy when households have debt: new evidence on the transmission mechanism." Review of Economic Studies, forthcoming.

Coibion, Olivier, Yuriy Gorodnichenko, Lorenz Kueng, and John Silvia. 2017. "Innocent Bystanders? Monetary policy and inequality." Journal of Monetary Economics, 88: 70 - 89.

De Nardi, Mariacristina. 2004. "Wealth inequality and intergenerational links." The Review of Economic Studies, 71(3): 743-768.

Eggertsson, Gauti B, and Paul Krugman. 2012. "Debt, deleveraging, and the liquidity trap: A Fisher-Minsky-Koo approach." The Quarterly Journal of Economics, 127(3): 14691513.

Favilukis, Jack, Sydney C Ludvigson, and Stijn Van Nieuwerburgh. 2017. “The macroeconomic effects of housing wealth, housing finance, and limited risk sharing in general equilibrium." Journal of Political Economy, 125(1): 140-223. 
Fieldhouse, Andrew J., and Karel Mertens. 2017. "A Narrative Analysis of Mortgage Asset Purchases by Federal Agencies." National Bureau of Economic Research Working Paper 23165.

Fieldhouse, Andrew, Karel Mertens, and Morten O Ravn. 2018. "The Macroeconomic Effects of Government Asset Purchases: Evidence from Postwar US Housing Credit Policy." Quarterly Journal of Economics, forthcoming.

Floetotto, Max, Michael Kirker, and Johannes Stroebel. 2016. “Government intervention in the housing market: Who wins, who loses?" Journal of Monetary Economics, 80: 106123.

Gonzalez-Rivera, Gloria. 2001. “Linkages between Secondary and Primary Markets for Mortgages: The Role of Retained Portfolio Investments of the Government-Sponsored Enterprises." The Journal of Fixed Income, 11(1): 29-36.

Greenspan, Alan. 2005. "Remarks by Chairman Alan Greenspan to the Conference on Housing, Mortgage Finance, and the Macroeconomy, Federal Reserve Bank of Atlanta, Atlanta, Georgia, May 19, 2005."

Greenwald, Daniel L. 2016. “The mortgage credit channel of macroeconomic transmission."

Hancock, Diana, and S Wayne Passmore. 2014. "How the Federal Reserve's Large-Scale Asset Purchases (LSAPs) Influence Mortgage-Backed Securities (MBS) Yields and US Mortgage Rates."

Hancock, Diana, and Wayne Passmore. 2011. “Did the Federal Reserve's MBS purchase program lower mortgage rates?" Journal of Monetary Economics, 58(5): 498-514.

Heathcote, Jonathan, Kjetil Storesletten, and Giovanni L Violante. 2017. "Optimal tax progressivity: An analytical framework." The Quarterly Journal of Economics, 132(4): 1693-1754.

Hedlund, Aaron, Fatih Karahan, Kurt Mitman, and Serdar Ozkan. 2016. "Monetary Policy, Heterogeneity, and the Housing Channel." Vol. 663.

Hilber, Christian AL, and Tracy M Turner. 2014. "The mortgage interest deduction and its impact on homeownership decisions." Review of Economics and Statistics, 96(4): 618-637. 
Huggett, Mark. 1996. "Wealth distribution in life-cycle economies." Journal of Monetary Economics, 38(3): 469-494.

Iacoviello, Matteo. 2005. "House prices, borrowing constraints, and monetary policy in the business cycle." The American economic review, 95(3): 739-764.

Jordà, Òscar. 2005. "Estimation and Inference of Impulse Responses Local Projections." American Economic Review, 95(1): 161-182.

Kaplan, Greg, Benjamin Moll, and Giovanni L Violante. 2017. “Monetary policy according to HANK." American Economic Review, forthcoming.

Kaplan, Greg, Kurt Mitman, and Giovanni L Violante. 2018. "The housing boom and bust: Model meets evidence." National Bureau of Economic Research.

Lehnert, Andreas, Wayne Passmore, and Shane M Sherlund. 2008. "GSEs, mortgage rates, and secondary market activities." The Journal of Real Estate Finance and Economics, 36(3): 343-363.

Luetticke, Ralph. 2015. "Transmission of Monetary Policy and Heterogeneity in Household Portfolios." University of Bonn Work in Progress.

Meltzer, Allan H. 1974. “Credit availability and economic decisions: Some evidence from the mortgage and housing markets." The Journal of Finance, 29(3): 763-777.

Naranjo, Andy, and Alden Toevs. 2002. “The effects of purchases of mortgages and securitization by government sponsored enterprises on mortgage yield spreads and volatility." The Journal of Real Estate Finance and Economics, 25(2): 173-195.

Piazzesi, Monika, Martin Schneider, and Selale Tuzel. 2007. "Housing, consumption and asset pricing." Journal of Financial Economics, 83(3): 531-569.

Quigley, John M. 2002. “Transactions Costs and Housing Markets." Housing Economics and Public Policy, 56-66.

Ramey, Valerie A. 2011. "Identifying government spending shocks: it's all in the timing." Quarterly Journal of Economics, 126(1): 1-50.

Romer, Christina D, and David H Romer. 2004. “A New Measure of Monetary Shocks: Derivation and Implications." American Economic Review, 1055-1084. 
Sommer, Kamila, and Paul Sullivan. 2018. "Implications of US Tax Policy for House Prices, Rents, and Homeownership." American Economic Review.

Wong, Arlene. 2019. "Refinancing and The Transmission of Monetary Policy to Consumption." Mimeo. 


\section{A. Agency and Market Data}

Below we describe the macroeconomic data used in the empirical section of the paper. We follow Fieldhouse, Mertens and Ravn (2018) closely in constructing the variables that we use. ${ }^{5}$ Residential mortgage debt is the sum of home mortgages and multifamily residential mortgages from the Federal Reserve's Financial Accounts of the United States. Nominal GDP is from the National Income and Product Accounts. Agency mortgage holdings is the sum of the retained mortgage portfolios of Fannie Mae and Freddie Mac. Between 1980 and 2003, the data on retained mortgage portfolio is available from various issues of Federal Reserve Bulletin. After 2003 the data is from Fannie Mae's and Freddie Mac's monthly volume summaries combined with annual OFHEO/FHFA reports. ${ }^{6}$ Residential mortgage originations before 1997 is from monthly releases of the Survey of Mortgage Lending Activity from the HUD. After 1997 the data on originations is available from Datastream (series USMORTORA) via The University of Manchester . Net portfolio purchases is the sum of corresponding series for Fannie Mae and Freddie Mac. Individual series before 2003 are available from various issues of Federal Reserve Bulletin. After 2003 the data is from Fannie Mae's and Freddie Mac's monthly volume summaries. Conventional mortgage rate is the 30-year fixed-rate conventional conforming mortgage rate, available at Freddie Mac mortgage market survey. Housing starts is obtained from FRED database at the Federal Reserve Bank of St. Louis (series HOUST). House prices is measured by the Freddie Mac house price index (FMHPI) available on Freddie Mac's website. Nominal price level is obtained from FRED database at the Federal Reserve Bank of St. Louis (series PCEPILFE). Personal income is obtained from FRED database at the Federal Reserve Bank of St. Louis (series PI). Unemployment rate is obtained from FRED database at the Federal Reserve Bank of St. Louis (series UNR). Short- and long-term interest rates are 3-month and 10-year Treasury rates, obtained from FRED database at the Federal Reserve Bank of St. Louis (series TB3MS and GS10). BAA and AAA corporate bond rates are the Moody's seasoned BAA and

\footnotetext{
${ }^{5}$ Please note that during the writing of this paper, the data and replication materials from Fieldhouse, Mertens and Ravn (2018) were not yet publicly available and all the variables described in the appendix are own calculations. As the data for Ginnie May was not available, it is excluded from the definitions of agency mortgage holdings and agency purchases. Similarly, net commitments were not publicly available for all years and were thus excluded. Other variables follow closely those of Fieldhouse, Mertens and Ravn (2018).

${ }^{6}$ Freddie Mac's monthly volume summaries that were not available online or via U.S. Securities and Exchange Commission for the years 2003-2008 were kindly provided by Freddie Mac's Equity Relations Department.
} 
AAA yields, obtained from FRED database at the Federal Reserve Bank of St. Louis (series BAA and AAA).

\section{B. Testing for Exclusion Restrictions}

Below we present the plot of robust F-statistics on the excluded instrument of the firststage regressions of cumulative agency net purchases given by equation (1) for different horizons $h$. Horizontal dashed line represents the threshold level of 10 .

Figure B.1: First Stage Robust F-statistic. Figure displays robust F-statistics on the excluded instrument of the first-stage regressions of cumulative agency net purchases.

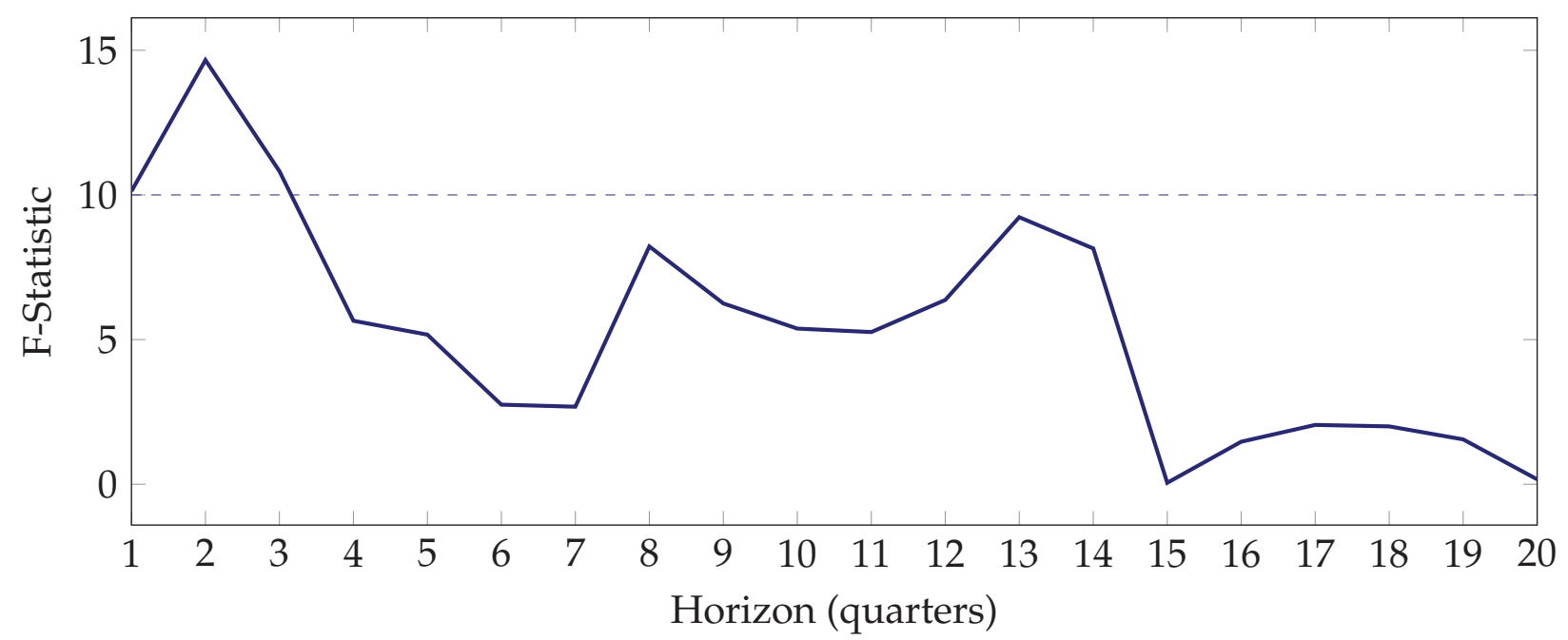




\title{
BANCO DE ESPAÑA PUBLICATIONS
}

\author{
WORKING PAPERS
}

1840 ALESSIO MORO and OMAR RACHEDI: The changing structure of government consumption spending.

1841 GERGELY GANICS, ATSUSHI INOUE and BARBARA ROSSI: Confidence intervals for bias and size distortion in IV and local projections - IV models.

1842 MARÍA GIL, JAVIER J. PÉREZ, A. JESÚS SÁNCHEZ and ALBERTO URTASUN: Nowcasting private consumption: traditional indicators, uncertainty measures, credit cards and some internet data.

1843 MATÍAS LAMAS and JAVIER MENCÍA: What drives sovereign debt portfolios of banks in a crisis context?

1844 MIGUEL ALMUNIA, POL ANTRÀS, DAVID LÓPEZ-RODRÍGUEZ and EDUARDO MORALES: Venting out: exports during a domestic slump.

1845 LUCA FORNARO and FEDERICA ROMEI: The paradox of global thrift.

1846 JUAN S. MORA-SANGUINETTI and MARTA MARTÍNEZ-MATUTE: An economic analysis of court fees: evidence from the Spanish civil jurisdiction.

1847 MIKEL BEDAYO, ÁNGEL ESTRADA and JESÚS SAURINA: Bank capital, lending booms, and busts. Evidence from Spain in the last 150 years.

1848 DANIEL DEJUÁN and CORINNA GHIRELLI: Policy uncertainty and investment in Spain.

1849 CRISTINA BARCELÓ and ERNESTO VILLANUEVA: The risk of job loss, household formation and housing demand: evidence from differences in severance payments.

1850 FEDERICO TAGLIATI: Welfare effects of an in-kind transfer program: evidence from Mexico.

1851 ÓSCAR ARCE, GALO NUÑO, DOMINIK THALER and CARLOS THOMAS: A large central bank balance sheet? Floor vs corridor systems in a New Keynesian environment.

1901 EDUARDO GUTIÉRREZ and ENRIQUE MORAL-BENITO: Trade and credit: revisiting the evidence.

1902 LAURENT CAVENAILE and PAU ROLDAN: Advertising, innovation and economic growth.

1903 DESISLAVA C. ANDREEVA and MIGUEL GARCÍA-POSADA: The impact of the ECB's targeted long-term refinancing operations on banks' lending policies: the role of competition.

1904 ANDREA ALBANESE, CORINNA GHIRELLI and MATTEO PICCHIO: Timed to say goodbye: does unemployment benefit eligibility affect worker layoffs?

1905 CORINNA GHIRELLI, MARÍA GIL, JAVIER J. PÉREZ and ALBERTO URTASUN: Measuring economic and economic policy uncertainty, and their macroeconomic effects: the case of Spain.

1906 CORINNA GHIRELLI, JAVIER J. PÉREZ and ALBERTO URTASUN: A new economic policy uncertainty index for Spain.

1907 ESTEBAN GARCÍA-MIRALLES, NEZIH GUNER and ROBERTO RAMOS: The Spanish personal income tax: facts and parametric estimates.

1908 SERGIO MAYORDOMO and OMAR RACHEDI: The China syndrome affects banks: the credit supply channel of foreign import competition.

1909 MÓNICA CORREA-LÓPEZ, MATÍAS PACCE and KATHI SCHLEPPER: Exploring trend inflation dynamics in Euro Area countries.

1910 JAMES COSTAIN, ANTON NAKOV and BORJA PETIT: Monetary policy implications of state-dependent prices and wages.

1911 JAMES CLOYNE, CLODOMIRO FERREIRA, MAREN FROEMEL and PAOLO SURICO: Monetary policy, corporate finance and investment.

1912 CHRISTIAN CASTRO and JORGE E. GALÁN: Drivers of productivity in the Spanish banking sector: recent evidence.

1913 SUSANA PÁRRAGA RODRÍGUEZ: The effects of pension-related policies on household spending.

1914 MÁXIMO CAMACHO, MARÍA DOLORES GADEA and ANA GÓMEZ LOSCOS: A new approach to dating the reference cycle.

1915 LAURA HOSPIDO, LUC LAEVEN and ANA LAMO: The gender promotion gap: evidence from Central Banking.

1916 PABLO AGUILAR, STEPHAN FAHR, EDDIE GERBA and SAMUEL HURTADO: Quest for robust optimal macroprudential policy.

1917 CARMEN BROTO and MATÍAS LAMAS: Is market liquidity less resilient after the financial crisis? Evidence for US treasuries.

1918 LAURA HOSPIDO and CARLOS SANZ: Gender Gaps in the Evaluation of Research: Evidence from Submissions to Economics Conferences.

1919 SAKI BIGIO, GALO NUÑO and JUAN PASSADORE: A framework for debt-maturity management.

1920 LUIS J. ÁLVAREZ, MARÍA DOLORES GADEA and ANA GÓMEZ-LOSCOS: Inflation interdependence in advanced economies. 
1921 DIEGO BODAS, JUAN R. GARCÍA LÓPEZ, JUAN MURILLO ARIAS, MATÍAS J. PACCE, TOMASA RODRIGO LÓPEZ, JUAN DE DIOS ROMERO PALOP, PEP RUIZ DE AGUIRRE, CAMILO A. ULLOA and HERIBERT VALERO LAPAZ: Measuring retail trade using card transactional data.

1922 MARIO ALLOZA and CARLOS SANZ: Jobs multipliers: evidence from a large fiscal stimulus in Spain.

1923 KATARZYNA BUDNIK, MASSIMILIANO AFFINITO, GAIA BARBIC, SAIFFEDINE BEN HADJ, ÉDOUARD CHRÉTIEN, HANS DEWACHTER, CLARA ISABEL GONZÁLEZ, JENNY HU, LAURI JANTUNEN, RAMONA JIMBOREAN, OTSO MANNINEN, RICARDO MARTINHO, JAVIER MENCÍA, ELENA MOUSARRI, LAURYNAS NARUŠEVIČIUS, GIULIO NICOLETTI, MICHAEL O'GRADY, SELCUK OZSAHIN, ANA REGINA PEREIRA, JAIRO RIVERA-ROZO, CONSTANTINOS TRIKOUPIS, FABRIZIO VENDITII and SOFÍA VELASCO: The benefits and costs of adjusting bank capitalisation: evidence from Euro Area countries.

1924 MIGUEL ALMUNIA and DAVID LÓPEZ-RODRÍGUEZ: The elasticity of taxable income in Spain: 1999-2014.

1925 DANILO LEIVA-LEON and LORENZO DUCTOR: Fluctuations in global macro volatility.

1926 JEF BOECKX, MAARTEN DOSSCHE, ALESSANDRO GALESI, BORIS HOFMANN and GERT PEERSMAN: Do SVARs with sign restrictions not identify unconventional monetary policy shocks?

1927 DANIEL DEJUÁN and JUAN S. MORA-SANGUINETTI: Quality of enforcement and investment decisions. Firm-level evidence from Spain.

1928 MARIO IZQUIERDO, ENRIQUE MORAL-BENITO and ELVIRA PRADES: Propagation of sector-specific shocks within Spain and other countries.

1929 MIGUEL CASARES, LUCA DEIDDA and JOSÉ E. GALDÓN-SÁNCHEZ: On financial frictions and firm market power.

1930 MICHAEL FUNKE, DANILO LEIVA-LEON and ANDREW TSANG: Mapping China's time-varying house price landscape.

1931 JORGE E. GALÁN and MATÍAS LAMAS: Beyond the LTV ratio: new macroprudential lessons from Spain.

1932 JACOPO TIMINI: Staying dry on Spanish wine: the rejection of the 1905 Spanish-Italian trade agreement.

1933 TERESA SASTRE and LAURA HERAS RECUERO: Domestic and foreign investment in advanced economies. The role of industry integration.

1934 DANILO LEIVA-LEON, JAIME MARTÍNEZ-MARTÍN and EVA ORTEGA: Exchange rate shocks and inflation comovement in the euro area.

1935 FEDERICO TAGLIATI: Child labor under cash and in-kind transfers: evidence from rural Mexico.

1936 ALBERTO FUERTES: External adjustment with a common currency: the case of the euro area.

1937 LAURA HERAS RECUERO and ROBERTO PASCUAL GONZÁLEZ: Economic growth, institutional quality and financial development in middle-income countries.

1938 SILVIA ALBRIZIO, SANGYUP CHOI, DAVIDE FURCERI and CHANSIK YOON: International Bank Lending Channel of Monetary Policy.

1939 MAR DELGADO-TÉLLEZ, ENRIQUE MORAL-BENITO and JAVIER J. PÉREZ: Outsourcing and public expenditure: an aggregate perspective with regional data.

1940 MYROSLAV PIDKUYKO: Heterogeneous spillovers of housing credit policy.

BANCODEESPAÑA Eurosistema
Unidad de Servicios Auxiliares

Alcalá, 48 - 28014 Madrid

E-mail: publicaciones@bde.es www.bde.es 